sciendo Порівняльна професійна педагогіка 8(4)/2018 Comparative Professional Pedagogy 8(4)/2018

DOI: $10.2478 /$ rpp-2018-0058

Postgraduate Student, OLENA MOSHENETS

Khmelnytskyi National University, Ukraine

Address: 11 Instytutska St., Khmelnytskyi, 29016, Ukraine

E-mail: elena.moshenets@gmail.com

\title{
PROFESSIONAL TRAINING \\ OF INTERNATIONAL COMMUNICATION SPECIALISTS: THE EXAMPLE OF COVENTRY UNIVERSITY
}

\begin{abstract}
The article deals with professional training of international communication specialists in Coventry University. It is found that professional training of specialists in information communication in Coventry University takes into consideration today's challenges imposed by globalization, internationalization and integration processes and is characterized by flexibility, transparency of learning goals, clear learning outcomes and orientation towards practical application of the acquired knowledge, abilities and skills. It is specified that the scope of academic modules allows future specialists to understand the need to grasp the essence of communication, digital communication, reflexive communication, communication history, ethical communication, strategic communication, peace journalism, etc. It is clarified that they are trained to deal with communication in critical situations and come up with most relevant solutions. Based on the accumulated data, the following steps are suggested to enhance the quality of professional training for specialists in international communication in Ukraine: to reconsider the scope of expertise in international communication and take into account the most important aspects of the field to adjust them locally, regionally and nationally, so that future Ukrainian specialists in international communication can participate in the debates on topical issues in the international arena; to update the content of professional training in international communication so that it can correspond to global and European challenges of integration, globalization and internationalizations processes; to establish partnership relations between Ukrainian and European higher education institutions so that Ukranian students can develop their learner autonomy and academic mobility; to equip classrooms with advanced technologies contributing to developing practical skills of international communication specialists; to involve future specialists in international communication in the organization of conferences, evens and seminars related to the field of expertise.

Keywords: international communication, international communication specialist, professional training, the UK, Ukraine, university.

\section{INTRODUCTION}

The declaration of Ukraine's independence, modernization of political processes, globalization of social life have greatly actualized the knowledge of international communication as an instrument for preserving the statehood and improving the image of Ukraine in the international arena. This issue is relevant not only for specialists in the field of mass communication, but also for the international staff. Communication has become one of the central components of modern society. Not only economic indicators determine the status of the state, but also its role in the international information space. Modern
\end{abstract}


sciendo Порівняльна професійна педагогіка 8(4)/2018 Comparative Professional Pedagogy 8(4)/2018

society has reached such a stage of its organization, which requires more efficient processes, both internal and external coordination. Indeed, the more developed the state is, the stronger it depends on information processes and technologies.

In the information and technology sector, there have appeared fundamentally new threats to states, organizations and individuals. The balance of forces in the international space has been violated. The problem of information security, which is based on the existing dependence of all spheres of society's life and the state on reliable functioning of information and telecommunication systems, technologies and means, has become more relevant than ever. The threat of national cultures deformation is rapidly growing. There appear new opportunities for expanding dialogue, cooperation and mutual understanding between the states. Without such cooperation, one cannot solve global problems of the present. International communication is directly related to all these problems and it itself can be seen as one of the most important global issues. Today's world cannot be closed within the same country and all specialists should be ready to interact and cooperate with international audience.

We strongly believe that it is vital for Ukrainian specialists in international communication to be able to correspond to the challenges of today and demonstrate vast knowledge and competence in dealing with the issues related to theory and practice of international communication through the prism of integration, internationalization and globalization processes. Currently, the UK is undergoing the period of reconsideration of all existed treaties and cooperations with the EU and has already gained recognition of its' specialists professionalism in the matters of international communication. Therefore, this study will attempt to outline the most positive aspects of the UK's experience in training such specialists so that they can be further implemented into the national practice.

\section{THE AIM OF THE STUDY}

The current research attempts to achieve the following: to analyze professional training of information communication specialists in the UK universities and outline relevant recommendations for enhancing the quality of professional training for these specialists in Ukraine.

\section{THEORETICAL FRAMEWORK AND RESEARCH METHODS}

International communication is a rapidly growing and complex area within communication and media studies. It is related to cultural commodification (when cultural products turn into commodities), informational diffusion by media empires globally, as well as the challenges the developing world currently deals with in the context of these processes. Within the context of such a New World Information order, it covers such issues as human and rights power, technologies and censorship. With regard to a concern with technology, it is focused on the roles of freedom, information and technology itself. It searches for some new ways of transnational communication. It monitors the activities of different international organizations (e.g. UNESCO) and non-governmental organizations (NGOs) (Mohammadi, 2005, p. 1).

V. Gupta (2005) exemplifies the broad trends in international communication with the annual report of the advertising giant Saatchi \& Saatchi and the statement of the Times editor Charles Douglas-Home. The first trend consists in the idea that an era of global communication has achieved the establishment of the global empire that is turning the world into one market place. Markets, products and services have become global and urge companies all over the world to compete in the global market place. Consequently, such globalization has affected advanced technologies and transformed information and 
communication. The second trend relates to the electronic age and the need of publishing enterprises to support newspapers. Ch. Douglas-Home emphasizes the importance of news in the global scale and its power to create some sense of community about it (Gupta, pp. 27-28).

A. Kavoori (2009) states that international communication is an area dealing with debates within/across international politics, anthropology, sociology ad comparative literature and mirroring all anxieties inherent in these fields. These include such issues as identity policies, globalization and policy formulations (p. 1).

It must be noted that the UK has been strengthening its international communicative capabilities since World War II. The British Broadcasting Corporation (BBC), the most representative media organization in the country, has become one of the most powerful media organizations in the world. Since 1994, white papers have been released to designate support of the $\mathrm{BBC}$ as for it participation in global competitions and reflect transparency and cultural variety of the UK. Consequently, the British media has occupied the most successful position in global media and enhanced the international image of the country. Today, the BBC is recognized for its powerful international communicative capacity and serves as a tool for achieving international political objectives of the country (Peng, 2017).

Given the presented views on international communication as a field it can be concluded that it encompasses many aspects related to information and communication technologies, broadcasting, interaction, cooperation, identities and policies. Having analyzed, generalized and systematized different sources such as the Subject Benchmark for Communication, Media, Film and Cultural Studies developed by QAA, programme specifications of individual British universities in international communication, we attempted to present relevant results on the problem of professional training of specialists in international communication in the UK and provide most clear recommendations to improve the quality of professional training for these specialists in Ukraine.

\section{RESULTS}

To begin with, it must be highlighted that QAA subject benchmark statements only characterize the essence and the academic standards expected to be achieved by graduates in specific fields. They describe what they are to understand, know and do (QAA, 2016).

The Subject Benchmark for Communication, Media, Film and Cultural Studies was revised for the third time in 2016 and includes modern views on the field of communication taking into account changes in the content of curricula and the essence of communication media. Thus, British educators indicate that social life mainly depends on constant developments and vast and varied use of communication in different contexts and, therefore, requires that degree programmes in Communication, Media, Film and Cultural Studies should emphasize the importance of communication, including international communication in the development of both local and global communities. In addition, they state that these programmes are intellectually related to humanities, social sciences, the arts and cover knowledge and competencies developed within professional practical areas (e.g. business, marketing, computing, design and advanced technologies).

It should be borne in mind that degree programmes in Communication, Media, Film and Cultural Studies are focused on communicative and cultural activities as the main factors in determining political and economic, social and psychological life. The names of the programmes may include the following: communication studies; media studies; digital, 
sciendo Порівняльна професійна педагогіка 8(4)/2018 Comparative Professional Pedagogy 8(4)/2018

film or screen studies; cultural studies; publishing and public relations; journalism; advertising; interactive media, etc. Interestingly, they are aimed at developing critical independence, creativity, reflexivity, flexibility of graduates.

These degree programmes also pay considerable attention to different concerns of the present and cover the following: 1) cultural, aesthetic and communicative systems and practices; 2) the key role of communication in people's individual and collective understanding of the past, the present and the future; 3 ) the importance of communicative and cultural processes in economic, political and social life; 4) the vital role of communication in economic and political national and international processes; 5) the links between public communication and culture and economic power, religion, age, gender, ethnicity, nationality, etc.; 6) the need for debates on legal, political and ethical aspects of communication in a democratic society.

In the UK, many universities offer degree programmes in International Communication. This research presents the experience of Coventry University, which, in our opinion, is the best example in the matter.

Thus, Coventry University is considered to be one of the most leading universities in the country and provides future specialists in communications with valuable experience of working for news corporations, national media outlets, etc. The University's bachelor programme in International Communications is aimed at providing future specialists with core communication skills required in public relations and journalism and teachers them to analyze the scope these fields globally. The programme can be either full-time ( 3 years) or part-time (4 years) (Coventry University, 2018a).

With regard to the content of the course, it familiarizes future specialists with a cultural context of communication, so that they can comprehend the functioning of communication processes and develop their own communication skills. Subsequently, future specialists are taught how to develop general and special skills in international communication with the help of various case studies and exercises, since it is important for them to understand modern communications industries. The final year of the study allows future specialists to study profession-oriented areas of communication to be competitive in the labour market. In detail, the modules within the BA in International Communications at Coventry University are as follows:

- YEAR 1: Introduction to Journalism; Introduction to Communicative Practice; Process of Communication; Digital Communication; Communication History; Reflexive Communicator

- YEAR 2: Professional Experience; Communication and Technology; Ethical Communication; Communication in a Crisis; Media in Context; Journalism and Society.

- YEAR 3: International Communications Dissertation / International Communications Final Project; Media Lab; Strategic Communications; Optional modules (Investigative Journalism and Political Reporting; Peace Journalism; Entertainment and Lifestyle Journalism; Tech and Gaming Journalism; Health Communication) (Coventry University, 2018b).

Therefore, the Bachelor's degree programme in International Communications provides future specialists with traditional communication competencies, skills and values and prepares them to critically and comparatively interrogate the meaning of these internationally important competencies in the delivery of professional skills.

As for teaching methods employed within the course, the degree programme is a vocational course, which consists of two main layers (critical and analytical) and integratively combines theoretical and practical training. As a result, future specialists can 
learn how to apply the acquired knowledge, abilities and skills in practice immediately, obtain feedback from both lecturers and peers and discover some novel and efficient ways of applying these knowledge, abilities and skills. The above-mentioned aspects of these specialists' training are complemented by modern assessment methods (reflective essays), since it is rather vital to integrate theory and practice to assist students in acquring life-long learning skills. In such a way, they can be prepared to fulfill their needs for professional developed after graduation.

It must be noted that according to the strategy for assessment designed by Coventry University assures fair assessment of all courses and provides students with the opportunity to monitor their progress and check whether they are able to achieve expected learning outcomes. Assessment forms traditionally include examinations, individual or group assignments, projects.

Upon successful completion of the bachelor's degree programme in International Communications, graduates should be able to:

1) understand historical, philosophical, cultural, commercial and social practices that have shaped, and continue to shape, global communication practices;

2) demonstrate sophisticated research skills to locate, collate, organise and utilise data from a variety of sources in order to critically analyse and understand the range of contemporary global communication forms and practices;

3 ) work with regards to policy and regulatory frameworks, adhering to professionally-defined codes of practice and industry standards, in the production of a range of products for a range of audiences;

4) work independently and collaboratively on a range of projects in a variety of professional roles, demonstrating teamwork, negotiation, organisational and decisionmaking skills;

5) develop a range of technical and creative skills to inhabit a wide-range of roles in the contemporary media and communication industries;

6) demonstrate intellectual curiosity, creativity and the potential for continuing creative and professional development in the international arena;

7) develop professional competencies in relation to corporate communications and strategic management, relevant to the communications industry (Coventry University, 2018b).

It is important to note that the degree cultivates reflective skills of future practitioners and brings together theory and practice so that future specialists in international communication can critically understand professional, cultural and social processes, contextualize various environments of international communication. In addition, graduates are expected to find their place within the global landscape of professional activity and demonstrate a high level of critical and practical competencies.

\section{CONCLUSIONS}

Therefore, as one can see from the information presented above, professional training of specialists in information communication in Coventry University takes into consideration today's challenges imposed by globalization, internationalization and integration processes and is characterized by flexibility, transparency of learning goals, clear learning outcomes and orientation towards practical application of the acquired knowledge, abilities and skills. The scope of academic modules allows future specialists to understand the need to grasp the essence of communication, digital communication, reflexive communication, communication history, ethical communication, strategic communication, 
sciendo Порівняльна професійна педагогіка 8(4)/2018 Comparative Professional Pedagogy 8(4)/2018

peace journalism, etc. They are trained to deal with communication in critical situations and come up with most relevant solutions.

Based on the accumulated data, we can suggest the following steps to enhance the quality of professional training for specialists in international communication in Ukraine:

1. It is important to reconsider the scope of expertise in international communication and take into account the most important aspects of the field to adjust them locally, regionally and nationally, so that future Ukrainian specialists in international communication can participate in the debates on topical issues in the international arena.

2. It is vital to update the content of professional training in international communication so that it can correspond to global and European challenges of integration, globalization and internationalizations processes.

3. It is imperative to establish partnership relations between Ukrainian and European higher education institutions so that Ukranian students can develop their learner autonomy and academic mobility.

4. It is essential to equip classrooms with advanced technologies contributing to developing practical skills of international communication specialists.

5. It is recommended to involve future specialists in international communication in the organization of conferences, evens and seminars related to the field of expertise.

Further studies should be focused on the problem of international communication specialists' professional training in the EU countries (Germany, France, Switzerland, Austria, etc.).

\section{REFERENCES}

1. Coventry University. (2018a). Retrieved from https://www.coventry.ac.uk/.

2. Coventry University. (2018b). International Communication BA (Hons). Retrieved from https://www.coventry.ac.uk/course-structure/UG/2019-20/fah/internationalcommunication-ba/.

3. Gupta, V. S. (2005). International communication: contemporary issues and trends in global information revolution. New Delhi: Concept Publishing Company.

4. Kavoori, A. (2009). The logics of globalization: studies in international communication. Lanham, MD: Lexington Books.

5. McPhail, T. L. (2013). Global communication: theories, stakeholders and trends. New York, NY: Wiley.

6. Mohammadi, A. (Ed.). (2005). International communication and globalization. A critical introduction. London: SAGE Publications.

7. Peng, D. (2017). International communication strategies on Chinese radio and TV networks: initial observations. Berlin: Springer.

8. Quality Assurance Agency. (2016). Subject Benchmark Statement: Communication, Media, Film and Cultural Studies. Retrieved from https://www.qaa.ac.uk/docs/qaa/subjectbenchmark-statements/sbs-communication-media-film-and-cultural-studies16.pdf?sfvrsn=4fe1f781_12.

9. Semati, M. (2004). New frontiers in international communication theory. Oxford: Rowman \& Littlefield Publishers, Inc.

10. Silverblatt, A., \& Zlobin, N. (2015). International communications: a media literacy approach. London: Routledge. 